\title{
The Prion Protein
}

Edited by: Jörg Tatzelt

Ludwig-Maximilians-University, Munich, Germany

Published: January 2010. Pages: 86

ISBN: Book: 978-1-912530-07-6 £159, \$319

Published by: Caister Academic Press www.caister.com

A conformational transition of the cellular prion protein $(\operatorname{PrP}(C))$ into an aberrantly folded isoform designated scrapie prion protein $(\operatorname{PrP}(\mathrm{Sc}))$ is the hallmark of a variety of neurodegenerative disorders collectively called prion diseases. They include Creutzfeldt-Jakob disease and Gerstmann-Stäussler-Scheinker syndrome in humans, scrapie in sheep, bovine spongiform encephalopathy (BSE) in cattle and chronic wasting disease (CWD) in free-ranging deer. In contrast to the deadly properties of misfolded $\operatorname{Pr} P, \operatorname{PrP}(\mathrm{C})$ seems to possess a neuroprotective activity. More-over, animal models indicated that the stress-protective activity of $\operatorname{PrP}(\mathrm{C})$ and the neurotoxic effects of $\operatorname{PrP}(\mathrm{Sc})$ are somehow interconnected.

In this timely book, leading scientists in the field have come together to highlight the apparently incongruous activities of different PrP conformers. The articles outline current research on celluar pathways implicated in the formation and signaling of neurotoxic and physiological PrP isoforms and delineate future research direction. Topics covered include the physiologcial activity of $\operatorname{PrP}(\mathrm{C})$ and its possible role as a neurotrophic factor, the finding that aberrant PrP conformers can cause neurodegeneration in the absence of infectious prion propagation, the requirement of the GPI anchor of $\operatorname{PrP}(C)$ for the neurotoxic effects of scrapie prions, the pathways implicated in the formation and neurotoxic properties of cytosolically localized PrP, the impact of metal ions on the processing of $\operatorname{PrP}$, and the role of autophagy in the propagation and clearance of $\operatorname{PrP}(\mathrm{Sc})$. The book is fully illustrated and chapters include comprehensive reference sections.

Essential reading for scientists involved in prion research.

Chapter 1. Prion Neurotoxicity: Insights from Prion Protein Mutants (Isaac H. Solomon, Jessie A. Schepker and David A. Harris)

Chapter 2. Prion Protein: Orchestrating Neurotrophic Activities (Vilma R. Martins, Flavio H. Beraldo, Glaucia N. Hajj, Marilene H. Lopes, Kil Sun Lee, Marco A. Prado and Rafael Linden)

Chapter 3. Autophagy, Prion Infection and their Mutual Interactions (Andreas Heiseke, Yasmine Aguib and Hermann M. Schatzl)

Chapter 4. Prion Protein and Metal Interaction: Physiological and Pathological Implications (Neena Singh, Dola Das, Ajay Singh and Maradumane L. Mohan)

Chapter 5. Targeting of the Prion Protein to the Cytosol: Mechanisms and Consequences. (Margit Miesbauer, Angelika S. Rambold, Konstanze F. Winklhofer and Jörg Tatzelt)

Chapter 6. The Role of GPI-anchored PrPC in Mediating the Neurotoxic Effect of Scrapie Prions in Neurons (Helois E.

Radford and Giovanna R. Mallucci)

\section{Order from:}

Caister Academic Press https://www.caister.com/order 
The Prion Protein

Edited by: Jörg Tatzelt (Published: 2010)

Plant Genomics

Edited by: Hany A. El-Shemy (Published: 2009)

Microbial Ecology: Current Advances from Genomics, Metagenomics and Other Omics

Edited by: Diana Marco (Published: 2019)

Plant-Microbe Interactions in the Rhizosphere

Edited by: Adam Schikora (Published: 2018)

Prions: Current Progress in Advanced Research (Second Edition)

Edited by: Akikazu Sakudo and Takashi Onodera (Published: 2019)

Microbiota: Current Research and Emerging Trends

Edited by: Takashi Matsumoto and Yoshio Yamaoka, (Published: 2019)

Porcine Viruses: From Pathogenesis to Strategies for Control

Edited by: Hovakim Zakaryan (Published: 2019)

Lactobacillus Genomics and Metabolic Engineering

Edited by: Sandra M. Ruzal (Published: 2019)

the most relevant aspects of the more than 200 recognized species of

the Lactobacillus genus

Cyanobacteria: Signaling and Regulation Systems

Author: Dmitry A. Los (Published: 2018)

Viruses of Microorganisms

Edited by: Paul Hyman and Stephen T. Abedon (Published: 2018)

Protozoan Parasitism: From Omics to Prevention and Control

Edited by: Luis Miguel de Pablos Torró and Jacob-Lorenzo Morales (Published: 2018)

Genes, Genetics and Transgenics for Virus Resistance in Plants

Edited by: Basavaprabhu L. Patil (Published: 2018)

DNA Tumour Viruses: Virology, Pathogenesis and Vaccines

Edited by: Sally Roberts (Published: 2018)

Pathogenic Escherichia coli: Evolution, Omics, Detection and Control

Edited by: Pina M. Fratamico, Yanhong Liu and Christopher H. Sommers (Published: 2018)

Postgraduate Handbook: A Comprehensive Guide for PhD and Master's Students and their Supervisors Author: Aceme Nyika (Published: 2018)

Enteroviruses: Omics, Molecular Biology, and Control

Edited by: William T. Jackson and Carolyn B. Coyne (Published: 2018)

"frontiers in the study of the 12 species of the genus" (ProtoView); "the current most important enterovirus research" (Biotechnol. Agron. Soc. Environ.)

Molecular Biology of Kinetoplastid Parasites

Edited by: Hemanta K. Majumder (Published: 2018)

"I would therefore recommend this book" (Parasites and Vectors)

Bacterial Evasion of the Host Immune System

Edited by: Pedro Escoll (Published: 2017)

"The figures are expertly drawn" (SIMB News) 